\title{
English and Irish Broadsides in the \\ Edwin Ford Piper Collection
}

\section{H A R R Y OS T E R}

It would be almost impossible nowadays to get together such another curious collection of these ephemeral trifles. They are mostly badly printed from hand-presses, with many quaint woodcut illustrations, though the illustrations very often do not appear to have any reference whatever to the ballad, and in some cases the same block has been made to do duty several times over. The compositions are coarse and vulgar, the rhymes are laboured to a degree that might have been turned out of a mangle, and taken together they are usually beneath contempt judged as literary productions, yet as an index to the taste of the lower orders of the period they are of much value and interest. ${ }^{2}$

Thus contemptuously did Albert Sutton, a bookseller of Manchester, England, describe a set of one hundred and fifty broadsides (most of them printed in Dublin or Manchester) lovingly mounted in a large scrapbook by an unknown collector in the nineteenth century, a collection now of considerable fascination for the typographer, bibliographer, folklorist, and historian.

Not deterred by Sutton's description in which snobbery vied with salesmanship, Edwin Ford Piper, the University of Iowa's omnivorous collector of folksongs, seized the opportunity to buy the scrapbook in 1914. It is now in the library's collections.

As reflections of history many of the broadsides are of special interest. The oldest is probably "Brave Nelson"; its focus on the Battle of Trafalgar suggests that it was printed in 1805 or shortly afterwards. The most recent, "Chicago Fire," deals with the disaster of 1871. Thus they appeared during the great upheavals of the nineteenth century. One gets a vivid picture of the impact of a changing economic system and the growing religious and political hostility between

${ }^{1}$ As quoted in Harold D. Peterson, "A Syllabus of the Ballad Collection of Edwin Ford Piper," unpublished master's thesis, The University of Iowa, 1934, p. 92. 
England and Ireland. Most of the major historical episodes of this period are treated in one or more ballads and embody central popular attitudes. We find accounts of the Battle of Peterloo, the death of George III, the Church Bill of 1832, the factory law of 1833, Victoria's assumption of the crown, the Irish poor law and the tithe bill of 1838, the Young Ireland movement of 1842, Ireland's plagues of the late forties-famine, absentee landlords, emigration, the corn laws; also factory and mine legislation of the same period, and the Woman's Rights Bill of 1851. Typical of ballads which embody current events of the time are "Amnesty Meeting in Tipperary," "Church Bill," "Collier Lass," "Factory Belle of England," "General Taxation," "Liberation of the Clergy," "Peterloo," "Rights of Man," "Exile of Erin," and "Emigrants Farewell to Donegall," part of which follows as an example of broadsides of social protest:

\section{Emigrants Farewell to Donegall}

Good people all on you I call give ear to those lines you soon shall hear Gaus'd [Caused] me to weep deprived of sleep for parting my relations dear My hardships here I can't injure [endure] there's nothing here but slavery, I wil take my lot \& leave this spot \& try the land of liberty. . . .

My father holds 5 acres of land it was not enough to support us all, Ohich [Which] bannishes me from my native land to old Ireland dear

I bid fa ew il [farewell],

My hardships here I cant injure since here no longer I can stay

I take my lot \& leave this spot \& try the land of liberty. . . .

It was in the ydar [year] of 46 I was forced to leave my native land

To old Ireland I bid a lang adieu and to my fond relations all,

But now I'm in America no rents or taxes we pay at all

So naw I bid a long farewell to my native and old Donegall.

About the conditions which led to such departures Disraeli wrote: ... these people were the worst housed, the worst fed, and the worst clothed of any in Europe. They live in mud cabins littered upon straw; their food consists of dry potatoes of which they are often obliged to stint themselves to one spare meal; sometimes a herring or a little milk may afford them a pleasing variety, but sometimes also they are driven to sea-weed and to wild herbs. Dwelling in hovels and feeding upon roots, they are clothed in rags.

Those were the ordinary circumstances of Ireland, and to such a state of affairs famine was now added with all its attendant horrors, pestilence and death. In the southern and western parts of the country the population was decimated....2

2 Benjamin Disraeli, Lord George Bentinck: A Political Biography, Second Edition (London, Colburn and Co., 1852), pp. 350-351. 
When reality is so horrifying, fantasy becomes especially attractive, as suggested in "Christmas Goose":

Good people all, both great and small, I pray you listen a minute, I'll sing to you a verse or two, there is something coming in it;

To buy a stunning Christmas Coose, I on a journey started,

And three half-crowns I did pay down for one in Wigan Market.

This goose was hatched in Noah's Ark, while on the ocean sailing One night as Noah was a sleep, she flew outside the railing.

And ever since she has been fed, upon the bog of Allen;

The devil a frog upon the bog, but what this goose had swallowed.

The stuffing that went into this goose, I'm told by the waiters, Was ninety-seven bags of flower and seventy bags of potatoes, Seventy pounds of onions sound, nine pounds of cayenne pepper, Besides there was the kidney suet, of Darby's fattest heifer.

The spit she was roasted on, made at an iron foundry, Twelve horses dragged it along, outside the parish boundary, And for a chain to turn the spit, belive me its no fable, I sent a friend to get the lend of Royal George's cable.

I sent out invitations then, as sure as I'm a sinner, For to collecting a nashing[?] set, to give them a Christmas Dinner; There was ninety-seven buy-a brooms came from the German nation With barbers' clarks and seventy grooms, to dine in full rotation.

There's tinkers tailors, soldiers, sailors, milliners \& paviors, There's minders, grinders, snobs, and sweeps, and fifty steam-loom weavers; At one o'clock on Christmas Day, collected in a stable, And to serve the gravy around to them I borrow'd a muckman's ladle.

The best of fun, the goose was done, according to our wishes, And knives \& forks played Bob and Joan upon the plates \& dishes, The table, dear me capsized, by some unruley ruffian, And three poor donkeys and a pig, was smother'd in the stuffing. The graey [gravy] of this Christmas goose you'd give a crown t'have tasted T'would raise the cockles of your heart, oh, what a sin to waste it; I collected all the gibblets up, and stuffed them in a bustle, And sent chem [them] away without delay, as a present to John Russell.

\section{CHORUS}

Talk about your Christmas Goose, but little I think about her, But here I am what you may call, a stunning out and outer.

The goose here described is on the surface the sort of creature which one would expect to find in a typical tall tale. At another level, the gigantic goose is part of a whimsical wish-fulfillment fantasy in which someone who often goes hungry pictures himself as having 
such an abundance of food that there are even some lowly parts of the bird left over to be mockingly sent to Lord John Russell, prime minister of England during the potato famines in Ireland in the 40's, who was much under attack for not undertaking "gigantic subsidies to feed a starving people."3

Also, some scholars like Leslie Shepard link the complex of European magical and humorous folksongs in which "monstrous animals are hunted, killed and divided" with ancient rituals of sacrificial hunting such as described in Frazer's Golden Bough, "vestiges of the great Aryan migrations of ancient times, stemming from the common source of Indo-European tradition."

Reflecting the bitter effects of frequent wars in nineteenth century Europe, the collection includes several broadsides which deal with the views and experience of soldiers and sailors. The best of such songs is "Molly My Darling Dont Leave Me," apparently an answer to the folksong "Johnny I Hardly Knew You," the moving lament of an Irish wife whose soldier husband returns from a war terribly maimed. These two broadsides were designed to be sung to the same tune (familiar in the United States in the Civil War song, "When Johnny Comes Marching Home Again").

Fatagued I am after a long campaign,

It's true it's true,

And better for me that I was slain,

It's true it's true,

Than enter the town of sweet Athy

With a wooden stump \& a patch on my eye

And worse than all without telling a lie

Faith Molly is going to leave mo, [me]. . . .

You say you do not know me now,

You do, you do,

You say you do not know me now,

You do, you do,

You say you do not know me now

With this war-like patch that adorns my brow

Its your own Jonny jewel do not kick

Faith Molly I'll die if you leave me. . . .

Oh Molly my darling I brought home a store

Its true its true.

${ }^{3}$ Herbert Paul, A History of Modern England (New York, The Macmillan Company, 1904), 1, p. 62.

${ }^{4}$ Leslie Shepard, The Broadside Ballad (Hatboro, Folklore Associates, 1962), p. 41 , 
O Molly my darling I brought home a stor,

Its true, its true,

O Molly my darling I brought yoo a store,

My knapsack is full it will hold notingmor [nothing more]

Three odd stockings a tunic \& 2 shurts that are tore,

Arrah Molly my darling ddnt [don't] leave me.

What harm if I lost a leg,

Its true, its true,

What harm if I lost a leg,

Don't you see they gave me a stout wooden peg,

And a clean discharge through this country to beg,

Molly my darling don't leave me.

The last two stanzas express the tragedy of the soldier's plight with overwhelmingly powerful irony.

Among the most significant traditional songs in the scrapbook is "Barley Corn."

There was three farmers in the north as they were pasing [passing] by

They swore an oath a mighty oath that barley corn should die

One of them sal [said] drwn [drown] him the other said hang him high,

For whoever will stick to bayley [barley] grain begging he will die

CHORUS

-With me fal la fa

They put poor barely in to a sack of a cold \& rainy day.

And brought him of [off] to autumn [?] fields \& burned [buried?] him in the clay

Frost and snow began to melt and the dew began to fall,

When barley grain put up eis [his] head \& soon surprised them al [all].

Being in the summer season and the harvest comeing on

It is seen he stands up in the field with beard like any man

The reaper came with his hook and use'd me barborously,

He caught me by the middle so small \& cut me above the knee,

The next came was the binder \& look'd on me with a frown

And in the middle there was a thissle that pull'd his courage down,

The farmer came with his pitchfork \& peirce'd to the heart

Like a theif a roage [rogue] or highwayman they tied me to the cart

The thrasher came with his big flail \& soon he broke my bones,

It would greive the heart of any man to hear my sighs and groans,

The next thing they done to me they steep'd me in a well

They left me there for a day \& a night until my bellp [belly] began to swell.

The next thing they doen to me they dried me in a kiln

The [They] used me ten times worse than that they groua'd [ground] me

in a mill,

The [They] used me in the kitchen they used me in the hall,

They used me in the parlour among the ladies all. 
The barely grain is a comical grain it makes men sigh and moan, For when they take a glass or two they forget their wife and home, The drunkard is a durty man he used me worse than all He drank me in his durty gut \& spew'd me against the wall.

Ballads celebrating the immortality of this powerful hero Drink, who in mythic fashion is resurrected despite such determined attempts to crush him, have circulated in England and Scotland for at least four hundred years and may well be considerably more ancient. The earliest written variant occurs in the Bannatyne Ms. of 1568 under the title "Why should not Allane honorit be?" in which grain turned into intoxicating drink is personified as Allan of Malt. In his adaptation "John Barleycorn-A song to its own tune," Robert Burns followed closely the fragment he remembered from tradition and concluded the song in similar folk idiom. He commented on this score, "I once heard the old song that goes by this name sung, and being very fond of it, and remembering only two or three verses of it, viz., the first second, and third, with some scraps which I have interwoven here and there"s [I completed it].

Among other areas touched on by the broadsides in Piper's collection are pictures of social life, drinking sessions, the henpecked husband, dances, weddings, balls, fairs, and races. Some ballads deal with picaresque heroes and outlaws like Ben Turpin and Roger O'Hare. There are two elegies in honor of distinguished and beloved clergymen. But as one would expect, the largest number of broadsides deal with love in a wide variety of situations, lovers triumphing over all obstacles, lovers separated by disapproving parents, an abandoned lover dying of a broken heart, trusting maidens tricked by unscrupulous seducers, two variants of "The Baffled Knight," Child Ballad No. 112 , in which a clever girl escapes into her father's house and then ridicules a man for allowing himself to be dissuaded from ravishing her when he had the chance, devoted young men abandoned in favor of old men with property, and various other love themes.

In approaching broadsides such as these one should not commit the ethnocentric fallacy of judging them by belletristic standards, by the touchstones of such poets as Chaucer, Shakespeare, Milton, and Keats. Rather one should judge (if one need judge at all rather than simply enjoy or analyze) these pieces in terms of the purposes for which they were intended, as works of journalism, as propaganda, as a means of stirring up the emotions, as popular entertainment, composed by a

5 James C. Dick, The Songs of Robert Burns (Hatboro Folklore Associates, $1962)$, p. 487. 
wide variety of writers, at first sometimes by poets and authors like John Skelton and John Heywood, priests like William Forrest and Leonard Stopes, or more typically in the nineteenth century by tavern poets who wrote ballads for a shilling each and a quire (twenty-four) of free copies. Viewed from such a point of view, broadsides were intended to be ephemera, designed to be sold on the street, sung, and thrown away like a daily newspaper. The broadsides which rise above mere topicality, which present story and emotion in language of universal appeal to the folk, survive as folksongs. The one hundred and fifty broadsides in the Piper Collection are especially valuable because of their wide range of themes, styles, typography, and qualities that make for extinction or durability in folk tradition. Scholars in several disciplines view with special interest these scraps of paper, revealing remnants of the bustling tide of humanity which once poured through the streets of Dublin and Manchester. Once for sale for a penny, these are precious relics of the past, "antique ballads, sung to crowds of old, now cheaply bought for thrice their weight in gold."6

${ }^{6}$ Shepard, p. 58. 


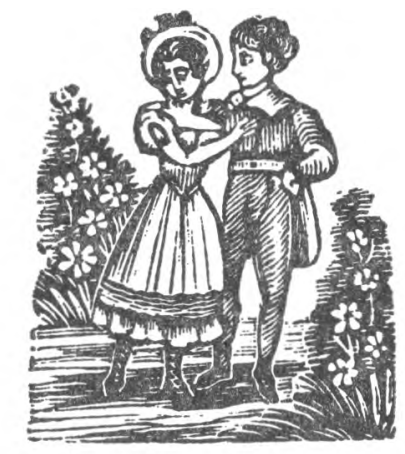

\section{Away to the Mountain's Brow.}

AwAY, away to the mountain's brow, Where the trees are gently waving-Away, away to the mountain's brow.

While the stream is gently laving;

And beauty, my love, on thy cheek shall divell,

Like the rose as it opes to the day, While the zephyr that breaths thro' the flow'ry dell,

Shakes the sparkling dew-drops away.

Away, away to the rocky glen,

Where the dear are wildly bounding, And the hills shall echo in gladness again

To the hunter's bugle sounding:

While beauty, my love, on thy cheek shall divell,

Like the rose as it opes to the day; While the zephyr that breathes thro' the Hlow'ry dell,

Shakes the sparkling dew-drops away. 